\title{
Areas of Improvement of Finance Policy in the Process of Advancing of Upgrading the Territorial Economic Activity and Financial Capacity
}

\author{
George Abuselidze ${ }^{1}$ \\ ${ }^{1}$ Departament of Finances, Accounting and Audit, Shota Rustaveli State University, Batumi, Georgia \\ Correspondence: Professor George Abuselidze, Shota Rustaveli State University, Batumi, 35. Ninoshvili street, \\ Georgia. Tel: 995-571-090-900. E-mail: abuseri@mail.ru
}

Received: March 10, 2013

Accepted: March 27, 2013

Online Published: April 17, 2013

doi:10.5539/ibr.v6n5p194

URL: http://dx.doi.org/10.5539/ibr.v6n5p194

\begin{abstract}
On the current stage, an important direction towards completion fiscal regulation is to regionalise economic and social processes, decentralize an important part of state functions on the local authorities. Herewith, to finance the expenditure by attaching appropriate income sources which will strengthen the role of local finances and assist the prosperity of regional economy. At the contemporary stage local budgets country, its separate regions development one of the most powerful leverage. Without them it is impossible political stability as in whole country, as in its separate regions. Local budget funds, social infrastructure forming are one of the major sources. Developed countries local budgets, density spare of social expenditures are higher than the state budgets. Local budget expenditures, especially on social provision spent funds promote in society social conflict softening that in contemporary conditions of each county's sustainable development stipulating factor.
\end{abstract}

Keywords: fiscal police, territorial budgets

\section{Introduction}

Regional economy peculiarity to some extent is determined by the country's regional policy which means on general understanding strategic social-economic purposes realization on individual territorial units. Proceeding from national interests and for the purpose of stimulation of economic development of the regions in terms of activation of mobilization of territorial budgets revenues the important problem of fiscal law includes its real placing into the frames of budget federalism. That is why, the matter of distribution functions between center and territorial units, as well as realization and consecutive observation of the principles of federalism in the process of exercising of interbudget relations is so actual.

Subject of research includes formation of territorial units budgets on the ground of optimization of revenues and the factors promoting socioeconomic development of territorial units.

The aim is to analyze the budget relations in the aspect of distribution of budget revenues between center and the regions in the period of transition; analyzing of the deficiencies typical for the existing order of distribution of revenues, which prevent formation of stable financial markets of territorial units budgets and further stabilization of their financial independence; proving of necessity of improvement of budget relations, their generalization and development of the appropriate proposals and recommendations.

Methods of research: Deduction, Synthesis, comparative analysis of scientific literature, statistical analysis, Historical approach.

\section{Literature Review}

This research is based on the methods and practical approaches, which are in practice and generalized in the Georgian and foreign economic writings and specially touch on the matters of budget relations and budgetary and tax policy, as well as the results of researches carried out in Georgia by international organizations. Informational background of this research includes legislative and normative acts adopted by the government of Georgia in the period of transition, information reported by the Ministry of Economic Development and Finances, National Service of Statistics of Georgia, Fiscal Committee of the Parliament, Ministry of Economic Development and Finance of the Adjarian Autonomous Republic and ministries and agencies, legislative and normative acts, information reporting by ministries of finance and national services of statistics of the developed and developing countries. 


\section{Survey}

In the modern period it is important to emphasize the legal aspects, which have the great importance for harmonization of the interests and interactions between state ruling groups, because any actions, exercising any policy at higher or lower hierarchic levels are carried out in the existing legal environment. Just correct determination of this legal environment means avoiding of conflicts between the priorities of general welfare in the society, as well as conflict between general tactics and strategy of actions.

For the purpose of deepening of budget decentralization clear segregation of the authorities of central and local government bodies is required.

Legal norms shall be adopted resulted thorough socioeconomic analysis and that of society for the purpose of further receipt of the basis for reduction of social inequality between social level to maximum extent, what will make a basis for equality of final results between the representatives of society as well as creation of equal basis in starting conditions.

Just that kind of measures includes formation of the territorial units and appropriate municipal and self-governing system, which provide, first of all, becoming of poor stratum of society a part of middle class society. This latter presents the main support, pillar, strength of any developed country state.

Generally, state policy in the sphere of self-governing shall be developed in three main filed, namely:

1) Involving of maximum quantity of people in local authorities;

2) Transfer of state functions to local bodies to more and more extent;

3) Creation of unions, associations of self-governing units and stimulation of their activity development.

This is an official policy. But factually, state structures often impede achieving of these strategic aims, as they consider self-governing their competitors. Nowadays unfortunately, there is no policy successfully conducting all above mentioned.

In this aspect Charter of Local Government adopted 1985 in Paris is very interesting. Its principles are considered guidelines for the countries of European Council.

In this respect, in terms of experience the law of France "On distribution of competences between communes, departments, regions and state", 1983, is interesting, as it finally strengthened the rights of communes (i.e. municipalities) autonomy, also, the analogical rights of departments were extended. Resulted this, position of Mayor of Paris became elective, besides the government appointed commissars instead of prefects to manage departments.

Certain reforms regarding self-government are being carried out also in Georgia from 90-s. But as a result we received only agglomeration of self-governing units, which strayed from the main object - human, for whom self-government became almost inaccessible.

Transfer of state functions to self-government is considered the most successful field among reforms of municipality, although in our country it could not give us the desired result as well. Setting up of associations also gave no results, as they remained without functions per se. That is why, groundless is the law provision, according to which central government before making decisions shall consult with the initiative groups of self-government, with associations concerning appropriate interesting matters, as they unify more than $60 \%$ of self-governing units.

Distribution of spheres between self-government and state may be understood mainly by means of distribution of private and social welfare. If we correctly divide these kinds of welfare in scientific respect, than even correlation of frameworks functions between self-government and state gets balanced, if not, it remains unbalanced. So, correct dividing shall give us guideline for distribution of the functions of coordination between state, self-government and market.

According to opinion of some scientists (Babich, Pavlova, Pronin), hierarchy of real self-government shall begin from bottom, i.e. micro-territories, as organization caring of satisfaction of all kinds of consumer wants. The best mean for that is just binding of municipal reforms to consumers' society.

Nowadays, just state resolves the problems of social welfare delivery, even in the spheres, where these problems belong to self-government and presents its exclusive right, because municipalities (self-governments) are considered immediate appendix of public administration and try to fulfill the functions delegated from superiors.

All above mentioned takes place, because if state does not distribute the sectoral functions, its interests are infringed. For example, nowadays, municipality disposes of land and collects land tax as well, what just state is interested in. But it is not very effective, because it is required to develop such mechanisms, where 
self-government will have more rights and public interests be protected as well.

The main aim of regulation of delivery of social welfare includes elimination of market shortcomings. If they are not eliminated, market delivers society negative external effects, and fails to deliver pure social welfare, because market works according to principle of gaining income and this welfare is of no interests of market.

Generally, welfare delivery is regulated as per the following methods: 1 . rendering service to state and municipality; 2. state and municipal subsidies; 3. government and municipal works (orders); 4.regulation of delivery by means of budgetary tax and money-and-credit instruments.

Proceeding from above mentioned, social protection strategy should be determined. For this purpose it is required to let each person act for satisfaction of its consumer interests and related economic ones, where self-government occupies strategic place and which shall merger with the two regulating forces: market and state. Factually, it is a mediator, interlink between market and state interests, which shall provide general social welfare, which is fulfilled with the regional united system and which key factors include economic and legal features:

1) preferences in the different territorial units and different stimulations between sectors;

2) activation of differenced prices mechanism after reduction of transactions costs;

3) subsidies of different sectors on regional and local levels; preferences, scholarships and subventions, establishing securities, including tax vouchers, tax vocations, i.e. amnesty etc.

It should be remarked, that distribution of taxes between the levels of governmental authorities may be fulfilled as per principle of decentralization of spending obligations, according to which distributing function of regional and local authorities includes proposing of state service to population of administrative territorial units. There are three variants of attaching of taxation authorities to subnational authorities:

1) Subnational authorities may be attached authority of regulation of all taxes collected at the territory located in the bounds of its jurisdiction. Besides, a part of revenues will be transferred to the higher level of budget system for satisfaction of spending obligation of state authority;

2) The second variant of distribution of taxation authorities in contrast to the first one provides transfer of all taxation authorities to state authority, as well as further transfer of money to lower bodies of government by the way of grants and transfers, also determination of standards of transfers of all/each taxes to lower level budgets. The main defect of this system is absence of relations between the level of government and that level of making decisions regarding bearing costs, on which territory this tax is collected, what is the main precondition for of setting up effective system of interbudget relations;

3) The third variant of distribution of taxation authorities includes transfer of concrete part of taxation authorities to local or regional authorities; in case of need insufficient revenue will be compensated by the way of transfer of share of regulating and attached revenues to local budget or by transfer. In implementation of such scheme of revenues distribution the key problem includes selection of taxes to be transferred to local or regional authorities (local or regional taxes), as well as state taxes, the concrete part of which is transferred to local or regional budgets, as regulating taxes.

As we consider, in respect of the problems of taxation authorities between the levels of state authorities in the bounds of traditional approach, the following rules of distribution of taxation authorities may be named:

1) intermediate, especially lower levels of subnational state authorities shall have authorities of taxation of tax base of more or less mobile type. Lower levels of management should be conferred authorities of collecting such kinds of taxes which are subject to moving between territories to minimum extend. Such distribution of authorities is effective in terms the interest of state and local authorities, because immobile tax base reduces potential of its penetration to the other administrative territorial units.

2) On the level of territorial unit progressive taxes on incomes of physical persons may be imposed in case of possibility of management of "global" tax base. As we pointed above, for the purpose of preclusion of distortion of distribution of recourses between territories income of individual or company shall be taxable to united rates and according to the rules of a territorial unit, to which this individual or company belongs. In terms of management the requirement of "globality" of tax base is difficult to meet towards income tax, but achievable while imposing income tax on physical persons, if the territorial unit is enough big.

3) While distribution of incomes between budget levels the authorities of taxation regulation should be attached on the national level of government. If adoption of policy of distribution of revenues on the national level, despite of belonging of individual to concrete territorial unit is a task of government of the country, the rules of taxation serving this task should be unitary on the whole territory of the country. 
4) Authorities of those taxes regulation, which are able to carry out stabilizing function, should be conferred to government. Bedsides, subnational taxes should be circularly stable. Application of instruments of fiscal policy for the purpose of economic stabilization is a primary function of government. In conditions of its multilevel system application of stabilizing mechanisms on the subnational level may cause significant losses, resulted reduction of total demand. Besides, it is notable, that government has also priority of application of the mechanisms of monetary and credit policy. Effective subnational taxes may include the taxes having high stability to cyclic fluctuations (property tax and consumption tax).

5) If inequality of tax base is distributed at the territory of the country, the authority of its imposing should belong to national government. It is clear, that territory rich in national recourses makes subnational authority able to render state service with lower "tax prices" (i.e. at account of comparatively lower level of taxation), what may cause ineffective application of recourses. So, authority of taxation of natural recourses distributed unequally on the territory of the country shall belong to government, although this statement conflicts to the fist rule given here above, according to which, different levels of government shall have authorities of taxation of tax base in accordance to their mobility.

As we think, in case of distributing of taxation authorities between the levels of government the following is required: 1. any political decentralization shall be followed by decentralization of spending and taxation authorities; 2.in case of distribution of taxation authorities between the state authorities of different levels, population of the territory shall take tax burden to such extent, to which it gains profit from social wealth offered by government.

Research of the problems of distribution of taxation authorities between the levels of state authority gives two opposite results: As per criteria of decentralization of spending authorities, a rule set determining distribution of taxation authorities between levels of state authority is in force. On the other hand, in terms of theory of social choice, analyzing of taxation authorities results necessity of strict conformity with spending and tax authorities on all levels of budget system.

The system of regulation of local budgets has the following positive features: it supplies local budgets with sufficient finances, creates network of cash drive and stimulates local authorities to maximize levy of local and central taxes.

Local budget revenues both in developed and developing countries are formed with secondary sources, mainly with property taxes. These revenues include also excises and dues. Definite part of local budgets is filled with municipal property revenues, namely, buildings rent, revenues from water supply and other communal services and various tax licenses. Revenues of federal budgets are different in various countries. For example, the main source of the USA states budget revenues include indirect taxes, i.e. sales tax and total gain (Ministry of Finance USA, official site: http://www.treasury.gov/resource-center/sanctions/Pages/default.aspx). As for land budgets of Germany, they mainly accumulate direct taxes, i.e. income tax, corporation income tax, property tax and succession duty (Ministry of Finance Germany, official site: http://www.bundesfinanzministerium.de). Issuing of loans is one of the important revenues sources of federal authority, that is why federal debt has a tendency of growth.

Self-governing unit has not stable and guaranteed financial recourses and poor revenue base of self-government causes serious problem. Besides, the revenues earlier belonging to self-government are completely taken by central authorities and factually, only property tax is remained with self-government. Collection of non-own taxes (target and special transfers and other risen finances) and their amount significantly depends on political decisions of government.

Government shall not confer many socials categories justified or unjustified tax remissions at the expense of self-government. Remissions granted by resolutions of central government shall be financed from the central budget.

The local revenues which will be used for exercising of exclusive authorities and those required for application of competences delegated by central government shall be clearly separated.

In case of transfer of delegated authorities self-governing units shall be mandatory provided the required financing, because they cannot finance their authorities by means of their own pure recourses.

The lower limit of equalizing transfers shall be fixed by law (ex.: al least $5 \%$ of state budget revenues). Such provision does not provide dependence of amount of transfer on subjective decisions.

At least $70 \%$ of budget deficit of self-government units is given to them from state budget by the way of equalizing transfer (Budget code of Georgia, official site: www.mof.ge). Formula for calculation of equalizing transfer: 


$$
T i=(R-R i) \times P i \times K \times 70 \%
$$

where $\mathrm{Ti}$ - equalizing transfer;

$\mathrm{R}$ - average annual revenue of all local self-governing units per head;

$\mathrm{Ri}$ - average annual revenue of concrete local self-governing unit per head;

i- quantity of population in self-governing unit

$\mathrm{K}$ - correcting coefficient, $\mathrm{K}=\mathrm{K} 1+\mathrm{K} 2$, where $\mathrm{K} 1$ - coefficient of highland; $\mathrm{K} 2$ - coefficient of underpopulated territorial unit. For calculation of coefficient of highland (K1) we shall take quantity of population of self-governing unit and population residing in territorial units. Based on these data we calculate specific share of populations residing in highlands given in percents to the total population of self-governing unit, but the given volume is differentiated according to its growth. Coefficient of underpopulated territorial unit (K2) is determined according to quantity of population and privilege is conferred to undepopulated self-governing unit. Government of Georgia issued Resolution approving above mentioned coefficients. Particularly, as per named Resolution, coefficient in the formula of calculation of transfer is determined as follows:

Highland coefficient

$\mathrm{K} 1=0,5-$ if $30 \%$ of population of self-governing unit resides in highlands;

$\mathrm{K} 1=1,0$ - if $30-70 \%$ of population of self-governing unit resides in highlands;

$\mathrm{K} 1=1,5$ - if $70 \%$ of population of self-governing unit resides in highlands.

Coefficient of underpopulated territorial units

$\mathrm{K} 2=1,8$ - if population of self-governing unit does not exceed 25 thousand; $\mathrm{K} 2=0,4$ - if population of self-governing unit is $25-30$ thousand; $\mathrm{K} 2=0,1$ - population of self-governing unit exceeds 50 thousand.

For successful realization of the principle of equalizing of regional economy we shall necessary differentiate levels of socioeconomic development of regions introducing the appropriate methods. The funds are transferred to the lower level of budget if it regularly and completely participates in formation of revenues of state budget, but has lack of own financial recourses. Only for this reason the superior budget transfers the sums to budget unit of lower level. The first aim includes maximum filling of state budget with revenues, after that sometimes the next budget level may not receive or partly receive planned transfer, although transfers are planned in all territorial units. If budget of any region having potential ability is more or less planned with hope of further transfer, then prospective of economic progress and development of this region is not stable. Besides, we have impression, that economic equalizing of the regions is only formality and its practical fulfillment is not priority, as in case of introducing of the principle of transfer, as we think, it is automatically kept in mind, that it is done not for economic progress of the region, but for elimination of economic lag in comparison to the other, more developed regions. Ex facte, it is good, if social programs are implemented in economically lagging regions without delay, but, as we think, it would be better, to use significant part of total transfer recourses planned by state budget of Georgia for progress and development of economically lagging regions, but in comparatively less lagging regions only necessary social expenses should be financed. For this purpose it is possible to allot special fund of transfers for progress of lagging regions, from where less-developed regions will be financed in order of extent of their economic lagging, what will gradually enable us to approximate the levels of development of territorial units by means of transfers.

For regions having potential abilities it is purposeful to be dependent on filling with budget transfers to less extent. Usually, when in comparatively more developed region non-fulfillment of revenues in any kind is fixed, the appropriate mechanism should be developed for resolving the problem. The measures are planned for maximum mobilization of revenues, efforts to find additional courses, determination of new relations and spheres of activity. i. e., authorities of region care of self-rescuing and self-affirmation. For the purpose of comparison, the best example of above mentioned the fact is, that on the modern stage importance of federal subsidies, grants and credits in the USA gradually reduces, what points to growth of the share of self-financing of local budgets.

Separately, we shall point to the difficulties typical for determination of transfer volume. Many opinions concerning improving of transfer mechanism have been expressed. Scientists offer various formulas for its distribution. For example, professor I. Meskhia (Abuselidze, 2006) offers the simple rule for determination of volume of transfer with use of the following formula:

$$
T=S-H_{1}+H_{2}+H_{3}
$$

where $\mathrm{T}$ - volume of transfers from central budget to region; $\mathrm{S}$ - mandatory cost to be born by local budget; $\mathrm{H}_{1}-$ revenue received from local taxes and duties; $\mathrm{H}_{2}$ - local non-tax revenues; $\mathrm{H}_{3}$ - revenue received with long-term 
economic standards.

According to other opinions, on this stage it is purposeful to determine volume of transfer for each region in accordance with quantity of population residing within its territory. Besides, parameters received with such approach shall be considered average constant, which shall be corrected taking into consideration urgent tasks rising before concrete region. As we consider, if necessity of transfer rises, it is purposeful to take into consideration not only such indexes, as density of population, natural climatic conditions, poverty level, per capita income, regions' demand of financial recourses for resoling of current socioeconomic problems, level of participation of region in formation of budget revenues and budget institutions credit arrears. This list shall be added such significant index, as the sum required for economic potential of region and internal spare reserves, which will really improve regions development level and resulted further economic growth resolve problem of equalizing of their economic and social development levels. According to such approach the formula may be added index $\mathrm{R}$ - which covers sums required for activation of local spare reserves, but difficult to be provided due to pure revenues of local budget. Resulted, above formula receives the following look:

$$
T=S-H_{1}+H_{2}+H_{3}+R
$$

But if state budget cannot bear additional costs for at least minimum financing of such programs, it would be better, if central authorities stimulate local tax initiatives by the way of maximum decentralization of functions and authorities of local authorities.

\section{Conclusion}

In the socio-economic development of the territorial units of the most important is the division of competences between the center and the regions. We believe competency should be solved in three ways: a) special competence center, and b) issues relating to the special powers in the region (territorial units), and c) issues relating to a single management. Here as it should be noted that the Constitution of Georgia clearly formulated questions, relating to a special central government, but said nothing about the competence of national and territorial units (Abuselidze, 2006).

In our opinion, such a model is acceptable demarcation of competencies, which will provide the definition of specific competences of central and local authorities, and those powers that are not within the purview of any one of them, refer to the issues of unified management.

In our opinion, the basis for demarcation of the financial powers of the center and regions, we can put two basic principles: according to the first principle must delimit the financial center and the ratio of the region, which is primarily meant for each of them the existence of an independent budget and stable sources of replenishment orders and the possibility of an independent their own finances. But the problem of maintaining the economic balance, which is the guarantor of national independence and the main factor in the socio-economic development, should not fall out of the daily routine. It previa ideology is the basis of the second principle of delimitation of central and regional finance, according to which the state within its territory have to ensure that financial equalization of territorial units, starting with low development, with the average of the country.

\section{References}

Abuselidze, G. (2004). South-Western Georgia of Tbel Abuseridze Epoch (Economical Situation). Publishing House of Science.

Abuselidze, G. (2006). Features of Formation and Functioning of Budgetary System of Georgia at the transitive stage. Publishing House of Science.

Babich, A. M., \& Pavlova, L. N. (2002). State and the Municipal finance.

Bogachyov, O. V., \& Amirov, V. B. (1997). Problemy of strengthening of budgets subjects federation and local government. Journal of Finance, 9.

Federal Laws on the Federal budget on 2002-2007.

Finance. The textbook: - St.-Petersburg, TK Velbi, the Prospectus, 2009 - 640 with Federalism and regional development in modern Russia. Methodological and institutional aspects: - Moscow, the St.-Petersburg academy of management and economy, 2006 - 2007.

Granberg, A. N. (2000). The state and regions. M. Urss.

Grjaznova, A., \& Markin, E. (2010). Finance. Publishing house: Infra Th, the Finance and statistics.

Laurels, A. N. (1995). Budgetary federalism and financial stabilization. Journal of Voprosy of Economy, 8. 
Lekcin, B., \& Shvetsov, V. (1998). Budgetary federalism in crisis and reforms. Economy questions, 3.

Leksun, V. N., \& Shvecov, L. N. (2000). State and regions. M. Urss.

Ljubimtsev's, V. (1996). Budgetary federalism of a problem and prospect. Journal of Economist, 1.

Ministry of Finance Canada. Retrieved from http://www.fin.gc.ca/fin-eng.asp

Ministry of Finance Georgia. Retrieved from http://www.mof.ge

Ministry of Finance Germany. Retrieved from http://www.bundesfinanzministerium.de

Ministry of Finance Italy. Retrieved from http://www.mef.gov.it/en/\#

Ministry of Finance USA. Retrieved from http://www.treasury.gov/resource-center/sanctions/Pages/default.aspx

Podjablonsky, L. M. (2010). The Finance. Publishing house: It juniti-is given.

Podporina, I. (1995). Transferty and Budgetary alignment. Journal of Rosiisky Economic, 12.

Pronin, L. I. (2000). Budgetary and reform of federal relations. Journal of Finance, 3.

Rubinin, S. K. (1994). Financial the policy and perfection of Interbudgetary relations. Journal of Finance, 3.

Comenko, A. D. (2004). State regulation of budgetary relations in the conditions of integration. Journal of Finance, 1. 